\title{
3 Archives and transitional justice
}

In countries where military dictatorships, racist and segregationist governments or communist regimes have been overthrown and replaced by democratic governments, archives have rapidly emerged as an essential feature of what is called "Transitional Justice" as they progress towards democracy. According to the definition of the United Nations: The notion of transitional justice comprises the full range of processes and mechanisms associated with a society's attempts to come to terms with a legacy of large-scale past abuses, in order to ensure accountability, serve justice and achieve reconciliation. For the International Centre for Transitional Justice (ICTJ), it may be defined as follows:

[T]ransitional justice is a response to systematic or widespread violations of human rights. It seeks recognition for victims and promotion of possibilities for peace, reconciliation and democracy. Transitional justice is not a special form of justice but justice adapted to societies transforming themselves after a period of pervasive human rights abuse. In some cases, these transformations happen suddenly; in others, they may take place over many decades.

The cornerstones of transitional justice and the battle against impunity are four of the tenets set out in the international standards on human rights: (a) the State obligation to investigate and prosecute alleged perpetrators of gross violations of human rights and serious violations of international humanitarian law, including sexual violence, and to punish those found guilty; (b) the right to know the truth about past abuses and the fate of disappeared persons; (c) the right to reparations for victims of gross violations of human rights and serious violations of international humanitarian law; and (d) the State obligation to prevent, through different measures, the reoccurrence of such atrocities in the future (OHCHR, 2014). Four basic mechanisms are proposed to help attain these goals: reparations for victims, trial of criminals, institutional reform and expurgation of officials who took part in the crimes perpetrated under the old regime and creation of truth commissions. New archival institutions, such as the Federal Commissioner 
for Stasi Records set up in 1990 in newly reunified Germany, have laid the foundations for a new era in the use of archives and records in defence of human rights.

While the relationship between archives and human rights exists at all levels, publications on the subject tend to focus exclusively on human rights violations and the defence of human rights in countries where abuses have occurred. This blinkered approach often means that, when speaking about archives and human rights in countries transitioning to democracy, the need for medium and long-term objectives with regard to archival policy tends to be overlooked. It is too easy to forget that public sector agencies require robust records management policies and an archival system synonymous with open, transparent societies respectful of human rights. A strong national archival system is essential to ensure that records important for the promotion and protection of human rights are preserved (OHCHR, 2015, p. 9).

But until a new system can be put in place, fledgling democracies need to face up to their pasts and, for this, they need records. Extraordinary provisional archival policy measures therefore need to be established so that archives can cease to be treated simply as cultural institutions but as key players in transitional justice. Archives are essential in supporting the mechanisms of which their institutions could form an integral part. This is potentially true of the many new-style archival institutions that have emerged in countries engaged in a process of political transition, from the Federal Commissioner for Stasi Records to the many different memory centres or archives.

Even in cases where the approach adopted to political transition was more one of studied amnesia than anything else, the quintessential example of which is post-Franco Spain, a number of more or less extensive practical transitional justice measures were introduced to come to terms with the past. These included the trial of those responsible for atrocities, the establishment of truth commissions and mechanisms conducive to reform and democracy or measures to rehabilitate victims and make amends for the damage they had suffered.

In the end, the approach adopted to transition is largely coloured by factors such as the existence of archives and records to show the full horror of the human rights violations perpetrated and the policies adopted to manage these records. By contrast, when politicians make the deliberate decision to forget or draw a veil over the past, the fate of records and archives is sealed with dramatic consequences. If there are no supporting documents, transitional justice will be hobbled, leaving it with few alternatives, which is why documents recording human rights violations must be kept, transparently managed and made accessible to citizens.

\section{Archives and the right to truth}

The right to truth, as we have seen from the preceding theoretical analysis, will only be possible if nations have the ability to know the truth about 
traumatic past events. For transitional justice in its various forms, the key instrument has to be truth commissions, which are usually official public institutions set up at the highest political level to put the past to rest. Members tend to be legal experts, well-known intellectuals and prominent personalities, all broadly representative and reputed in their fields. Most truth commissions also have the word "reconciliation" tagged on to their title to emphasise the fact that their role is also that of rising above the past and preventing denial and recurrence. A large number of truth commissions have been set up in more than 35 countries where repressive regimes have finally been ousted, on the basis of this approach of seeking to reach consensus on a shared version of the traumatic events of the past. ${ }^{31}$

It is important to remember that the right to the truth is a collective right that has no limits in time and space. No limits in time, in the sense that records will be used long after they have fulfilled the functions for which they were originally intended, and no limits in space because they can be, and have already been, used outside the national boundaries of their "home" countries.

The Red Cross International Tracing Service Archive, in Bad Arolsen is perhaps the perfect example of this cross-border dimension, because it can provide information about Holocaust victims to a substantial number of people in many different countries anxious to learn their loved ones' fate. Information comes from records produced by the authorities in charge of the Nazi concentration and death camps and is managed by the International Tracing Service (ITS), which since May 2019 is named Arolsen Archives, International Centre on Nazi Persecution (Borggräfe, Höschler, and Panek, 2019). Eloquent illustrations of the international role of this agency are the sentences pronounced against war criminals or court rulings in cases brought against individuals accused of crimes against humanity (Arendt, 1963; González Quintana, 2011).

State security records in countries that have gone from totalitarian to fully democratic regimes, such as those of the Stasi in Germany or the secret police in other countries (Schiller-Dickhut and Rosenthal, 2014), are probably the best example of records that are both timeless and intergenerational. These records, which were originally used by dictatorships as weapons of persecution and repression, now constitute vital evidence for rehabilitating victims of human rights abuse and for ensuring redress, not only during the political transition phase but also when judging wrongdoers and for bringing the truth about events in the immediate past to light. To paraphrase the eminent Dutch archivist, Eric Ketelaar (1992), they have become archives "for the people" instead of "against the people".

In this process of trying to uncover the truth about past events, Spain is the prime example of the intergenerational importance of archives. The protagonists of the major changes that took place in Spain between 1977 and the end of the 20th century took the decision not to enforce policies for managing the past, on the pretext that, without them, democracy would be more easily achieved. Recourse to archives was only made in a few modest 
cases of reparation. But 30 years after the start of the transition process in Spain, the younger generations began to demand explanations for studiously occulted episodes of the past, for example about the whereabouts of missing persons. More generally, they wanted to know the truth about the atrocities perpetrated during and after the Civil War. And to provide them with the explanations they were demanding, archives and records were an essential part of the process. In the early stages of political transition in Spain, from 1975 to 2004, ignorance was the order of the day. This is borne out by the decision to rename documentary fonds of an obviously repressive nature, such as those produced by Franco's intelligence services in Salamanca between 1937 and 1977. These were to become the "Civil War" Section at the National Historic Archives (Archivo Histórico Nacional) before being renamed the "General Archive of the Spanish Civil War" and, since 2005, ${ }^{32}$ the Historical Memory Documentary Centre (Centro Documental de la Memoria Histórica) as though they were simply an academic research centre within an archiving system, on a par with the General Archive of Simancas (Archivo General de Simancas) or the General Archive of the Indies (Archivo General de Indias). Instead of simply offering researchers a set of documents for piecing together the history of the Civil War, it would in reality have been better, under transitional Spain's new legal framework, to face up to the task of managing a vast series of records produced by the system used by the police to control the population and containing 40 years of information about individual Spaniards. From the very first laws on reparation for Civil War victims, it was immediately obvious that this was what should have been done.

But the backdrop to transition was to change dramatically two decades later. Spain was inevitably caught up in the general movement of the $1990 \mathrm{~s}$ and the insistence that the truth about crimes against humanity and genocides and other similar atrocities be revealed. This wave of opposition to the principle of impunity put demand for memory, truth and justice on a common course. After the experience of the truth commissions, the establishment of the International Criminal Court in 1998, the actions of Judge Baltasar Garzón in recognising the universal jurisdiction of this Court in prosecuting Augusto Pinochet or against the perpetrators of repression in Argentina and the appearance of pro-memory movements in Latin America and Europe, associations for the recovery of historical memory began to spring up throughout Spain. In Part 2, Chapter 8, Henar Alonso Rodríguez offers further analysis of the particular case of Spain.

\section{Archives and the right to justice}

As rightly pointed out by Trudy Huskamp Peterson (2011, 2014; see also her Chapter 1, Part 2 in this book), while records may be universally used in trials, not all documentary evidence is equally reliable. She reminds us that, in 2006, the High Commissioner for Human Rights published research into 
the rules to apply in trials, highlighting the "vital" importance of documentary evidence: Documentary evidence may have advantages over personal testimony, as it may help to prove matters more quickly and succinctly. It is not subject to the difficulties presented by intimidation and changing disposition of witnesses. Although always subject to interpretation, it can often provide more conclusive evidence of specific events or orders than personal recollections or conjectures (OHCHR, 2015, p. 13).

The Nuremberg trials amply demonstrated the importance of archival documents and their significance in criminal trials. But the evidence used to judge war crimes or crimes against humanity in the aftermath of World War II points clearly to the determination of the Allies to convict senior Nazi officials. The lengthy Nuremberg trial clearly flagged up the importance of collecting evidence and of using expert skills to process the piles of records produced by the National-Socialist state machinery and, more particularly, its repressive agents or those of the party in power. The best confirmation of this is to be found in the outline provided by Robert G. Storey, Executive Trial Counsel for the United States at the Nuremberg Trial, of "the method of capture, processing and assembling documentary evidence used at the Trial, and the plan of presentation to the Tribunal" (Trial, 1947).

In his deposition before the tribunal, Storey explains that

as the United States Army advanced into German territory, there were attached to each Army and subordinate organisation specialised military personnel whose duties were to capture and preserve enemy information in the form of documents, records, reports and other files. The Germans kept accurate and voluminous records. They were found in Army headquarters, government buildings and elsewhere. During the later stages of the war particularly, such documents were found in salt mines, buried in the ground, behind false walls and many other places believed secure by the Germans. For example, the personal correspondence and diaries of Defendant Rosenberg, including his Nazi Party correspondence, were found behind a false wall in an old castle in Eastern Bavaria. The records of the Headquarters of the Air Staff (Luftwaffe) were found in various places in the Bavarian Alps. Most of such Air Force records were assembled and processed by the Army at Berchtesgaden. When the Army first captured documents and records, they immediately placed the materials under guard and later assembled them in temporary Document Centres. Literally hundreds of tons of enemy documents and records were screened and examined and those selected were forwarded to Nurnberg for processing.

These documents were essential in establishing the guilt of the accused.

But the Cold War was to thwart the movement set in motion in Nuremberg, not only in that politicians were no longer determined to haul the criminals before the courts, but also, paradoxically, in that they welcomed 
former criminals with open arms into their Security services to help them in the battle against their new enemies. The classic case in point is that of Klaus Barbie, who was accused of crimes against humanity for his role as the head of the Gestapo in Lyon. Demands by the French Government were consistently ignored by the U.S. authorities for whom Barbie was a kingpin in their anti-communist efforts. He was even recruited by the U.S. intelligence services, first in Europe and later in Latin America, to collaborate with the agencies combatting "subversive movements". In Bolivia, he was the main adviser to Banzer's and García Meza's totalitarian regimes in their efforts to quell their political opponents. The following documentary evidence is a damning proof that the accused, Luis García Meza and Luis Arce Gómez, were the organisers of armed paramilitary groups patently under their immediate authority and control. Perhaps the strangest and most incredible evidence is the undertaking signed on 12 February 1980 by Klaus Altmann Hansen - alias Barbie - and the accused Luis Arce Gómez, who, at the time, was in charge of Department 2 of the Army, which reads as follows:

I I, Klaus Altmann Hausen, ${ }^{33}$ undertake unconditionally to provide services to the Bolivian Army in respect of intelligence.

II I also undertake to play a direct part in planning and operations as required by the Bolivian Army, in which my active involvement is required.

III I promise, on my own head, to maintain secrecy with regard to everything that may occur or exist, everything that I know of or in which I may take part.

IV I, Colonel, DAEM, Luis Arce Gómez, in the name of the Army of the Nation and the obligations incumbent upon me, and with the approval of my hierarchy, hereby bestow the rank of Honorary Lieutenant on Mr Klaus Altmann Hausen.

The aforementioned document, signed by the accused, Luis Arce Gómez, on 12 February 1980 and by a foreign national convicted of "war crimes" by the French courts, is evidence of the preparations made to organise irregular groups with the consent of Luis García Meza. It is therefore amply demonstrated that the above-mentioned individuals set about the premeditated organisation of irregular groups, these groups then acting under their direct orders; /. . . /

(Supreme Court of Justice of the Nation. Court ruling in the lawsuits brought by the Attorney General's Office and other plaintiffs against Luis García Meza and his associates. 21 April 1993. Sucre, Bolivia)

It would be wrong to say that no war criminals or perpetrators of genocides, Nazi criminals in particular, were brought to trial during the Cold War period, but prosecutions were internal to the countries where the crimes had taken place: Poland, Soviet Union, Hungary, etc. (with the notable exception of Israel). More remarkably, trials were also staged in 
Germany following the creation of the Central Office of the State Justice Administrations for the Investigation of National Socialist Crimes in Ludwigsburg in 1958 (Schrimm and Riedel 2008, pp. 525-555). The trial of Adolf Eichmann in Jerusalem in 1961 made headline news worldwide, not least because of Hannah Arendt's controversial trial report (1963). Eichmann, one of the major protagonists with regard to the "Jewish question" under the Nazi administration and one of the main organisers of the "Final Solution" that culminated in the Holocaust, was brought to trial by the State of Israel, following his abduction by the Israeli Secret Service.

In France, the 1980s saw the start of a series of trials against "forgotten" prominent officials in France's collaborationist Vichy government, not least René Bousquet and Paul Touvier, as well as Maurice Papon, whose trial was to be the high point (Kitson, 2000). The large-scale trial of the military juntas in Argentina, in which the dictators were given heavy sentences for their crimes, also took place during this period, although the "Full stop" and "Due obedience" laws that immediately followed effectively rendered these sentences null and void. Last but not least, after his extradition to France, in 1983, Klaus Barbie was, in 1987, tried and sentenced to life imprisonment in highly mediatised court proceedings (Mateva, 2006).

However, as Manuel Ollé points out, it was the Ad Hoc Criminal Tribunals for the former Yugoslavia (1993) and Rwanda (1994) that truly signalled the revival of the Nuremberg spirit. The difficulty is that these supranational courts were deliberately vested with limited powers which made it impossible for them to try all the cases of crimes against humanity or genocide brought to their attention. Separate tribunals were therefore set up in each national case (Sierra Leone, Lebanon, etc.). But it was only when the International Criminal Court (ICC) came into being in 2002, following the adoption of the Rome Statute of the ICC in 1998, that there finally existed a tribunal qualified to judge crimes of this nature over and beyond national boundaries. Even then, the Court was to limit the scope of its jurisdiction to crimes committed after 2002 (Ollé Sesé, 2009).

The widespread application of the principle of universal jurisdiction was the apotheosis of moves in support of demand for remembrance, truth and justice. "Universal jurisdiction" allows jurisdictional bodies to prosecute and pass judgement on crimes of this nature when the countries where they occurred fail to take the necessary action. The cases that acted as pathfinders in this respect were the retrial in Spain of ex-members of the Argentinian military juntas in power between 1976 and 1983, who had benefitted from the amnesty laws and, more particularly, the trial of Augusto Pinochet, which stands out for its impact and significance. While the trials of Eichmann and Barbie may have set precedents, they were no more than delayed reflections of "international post-war justice" designed to punish Nazi criminals and their accomplices in the Holocaust.

The case of Augusto Pinochet is also interesting in that it was the first time that, in the name of the universal jurisdiction enshrined in the conventions 
giving the Nuremberg Principles their place in law, a magistrate from a third country, Baltasar Garzón, was able to bring to trial in Spain, a man who was not a Nazi war criminal but a Latin-American dictator accused of gross human rights violations, completely distinct from the Jewish genocide. This trial paved the way for similar action on the part of growing numbers of other countries in Europe and the Americas. In Italy, the investigations conducted by prosecutor Giancarlo Capaldo culminated in the indictment, at times in absentia, of a number of Latin American dictators on the charge of having caused Italian nationals to disappear (Barrera, 2011). A landmark example was that of the trials of Chadian dictator Hissène Habré, the final upshot of which was his conviction by the Extraordinary African Chambers. The trials were facilitated by the discovery and use of the records of his secret police, which played a decisive role in securing his conviction. The trials and the use made of these documents are analysed in Part 2, Chapter 4 by Henri Thulliez. In Guatemala, many of those responsible for gross human rights violations during the Civil War were brought before the courts as a result of documents supplied by the Historic Archive of the National Police (Archivo Histórico de la Policía Nacional).

\section{Archives and the right to reparation}

Ensuring long-term preservation of records produced in connection with political repression is essential because such records can provide unique evidence of the sufferings of people. In new democracies, the strongest argument for preserving records that provide proof of human rights violations are, firstly, their importance for the victims of repression and, secondly, their major role in the new political climate in enabling citizens to claim their individual rights: rehabilitation, amnesty, reparation, compensation, pensions and return of confiscated assets. Records are vital to show what happened to the victims and how they were abused, so they or their relatives can qualify for reparation, justice and knowledge of the truth. Trudy Huskamp Peterson deals with these questions in her essay "Proof", reproduced in this book (Part 2, Chapter 1). Archives, which were essential for stamping out political, religious, ethnic or ideological dissension and which were a fundamental part of the former repressive regimes, can be converted under the rule of law into irreplaceable weapons for enabling victims to exercise their rights to redress for the harm suffered and for imposing sanctions on those responsible for the atrocities perpetrated. This has been referred to as the "boomerang effect" of archives and records created for use in political repression and to exert control over the lives of the population (González Quintana, 1997).

The right of the victims of human rights violations to reparation, whether material or symbolic, has been recognised by the United Nations in a large number of documents and by several of its special rapporteurs. While there exists the precedent of the compensation paid by Germany to Nazi victims, ${ }^{34}$ 
it was the principles established by the United Nations with regard to reparation (UN, 2006) that were taken as a basis in many countries for their reparation schemes for the victims of political repression or human rights violations. The UN studies in this field started in 1988 (Cruz, 2010) and the first report from the UN special rapporteurs on impunity and reparation dates from 1993. It was the work of Theo van Boven, revised and expanded a few years later by Cherif Bassiouni, which laid down the basic principles and fundamental guidelines to be used as a basis for victim reparation policies:

Under international law, the violation of any human right gives rise to a right of reparation for the victim. Particular attention must be paid to gross violations of human rights and fundamental freedoms, which include at least the following: genocide; slavery and slavery-like practices; summary or arbitrary executions; torture and cruel, inhuman or degrading treatment or punishment; enforced disappearance; arbitrary and prolonged detention; deportation or forcible transfer of population; and systematic discrimination, in particular based on race or gender.

And for victims to be able to exercise their rights, there is a condition directly involving archives:

1. . .117. Every State shall make readily available all evidence in its possession concerning human rights violations. 18. Administrative or judicial tribunals responsible for affording reparations should take into account that records or other tangible evidence may be limited or unavailable. In the absence of other evidence, reparations should be based on the testimony of victims, family members, medical and mental health professionals.

In his report, Bassiouni (2000) confirmed the right of victims to stake their claim to justice, reparations for the harm suffered and access to information about violations. On the issue of reparation, they should be entitled to adequate, effective and prompt remedy. Reparation may take the form of restitution, compensation, rehabilitation or satisfaction, and it guarantees on non-repetition. The report also includes a section on the right of victims to accede to information. For archivists, this is of particular interest. In Part XI of the report on "Public access to information", Cherif Bassiouni stipulates that

States should develop means of informing the general public and in particular victims of violations of international human rights and humanitarian law of the rights and remedies contained within these principles and guidelines and of all available legal, medical, psychological, social, administrative and all other services to which victims may have a right of access. 
A third report, submitted by the rapporteur, Alejandro Salinas, in 2004, was instrumental for the approval of the Basic Principles on the Right to Remedy and Reparation for Victims of Gross Violations by the UN General Assembly in 2005. The following paragraph is a quotation from this report, selected because it deals with access to relevant information about violations and repair mechanisms and introduces a number of major nuances to the version of the text of the Bassiouni report mentioned previously:

States should develop means of informing the general public and, in particular, victims of gross violations of international human rights law and serious violations of international humanitarian law of the rights and remedies addressed by these Basic Principles and Guidelines and of all available legal, medical, psychological, social, administrative and all other services to which victims may have a right of access. Moreover, victims and their representatives should be entitled to seek and obtain information on the causes leading to their victimisation and on the causes and conditions pertaining to the gross violations of international human rights law and serious violations of international humanitarian law and to learn the truth in regard to these violations.

Mention should also be made of the work of another rapporteur, Sergio Pinheiro, even though it only concerns one very circumscribed aspect of reparation policies, namely the right to housing and property restitution in the event of the return of refugees and internally displaced persons (war, disaster or political repression). In his report on the Principles with regard to the restitution process, he includes highly interesting references to the role of records and documentation. ${ }^{35}$ Archiving practices vary widely with regard to the documents made available to victims to enable them to enjoy the benefits of reparation and compensation schemes. One of the positive ways in which archives and records may be used to obtain reparation may be illustrated by the example of Spain: even though there were no specific reparation arrangements in place during political transition, a large number of laws were however produced covering not only pensions and compensation but also recognition for the victims of political violence under Franco and during the Civil War.

With the demise of the Franco regime and from the start of political transition until the introduction of the first laws on reparations following the approval of the Amnesty Law (Turrión, 2013), Spain ordered the "Civil War" Section of the National Historic Archives to make the necessary documents available to those entitled to benefit from the initial legislation. This is extremely significant, because, as we have seen, the first stage in the transitional process was otherwise devoid of conventional transitional justice measures (knowledge of truth, allocation of responsibilities, etc.). From 1990, the role of archives as part of reparation policies was extended to other national archives, to military archives and to further public archives 
such as those of the Court of Auditors, more particularly following approval of the proposal to compensate victims of repression for the duration of their imprisonment on political or ideological grounds. Archival institutions had to deal with huge number of enquiries during this period; over 100,000 people were seeking documents and information to support their reparation claims (González Quintana, 2007).

The systems put in place in Colombia, in application of the 2011 Victims Law, or in Guatemala, in the wake of the 1996 Peace Agreements, produced very mixed results, partly because of difficulties in producing reliable evidence, in particular archives and records. This does not mean that they were not ambitious. In Colombia, the problem may be ascribed to the highly complex institutions put in place, as Ramón Alberch i Fugueras tells us in Part 2, Chapter 13. In Argentina, the records of the National Commission on the Disappeared were at the heart of the reparation programmes for, without them, it would have been virtually impossible to establish the fate of victims. In Chile, for enforcement of Law 19.123 of April 1993 on the first redress owed to victims of dictatorship, it was access to the lists of victims contained in the final report from the National Commission for Truth and Reconciliation (CVR) which was the vital first step towards identifying further victims of gross human rights violations, in addition to those on the Commission's initial list (Hayner, 2011). In the process, collecting documentary evidence and personal testimonies was of crucial importance and involved using the documents inherited from the CVR and the reports obtained from the Vicariate of Solidarity (Vicaría de la Solidaridad) as a basis for extending research to a large number of government agency offices.

Several other countries have enforced reparations laws or programmes, among them being Brazil, Morocco, Peru, Portugal, Czech Republic, Sierra Leone and South Africa. In Part 2, Chapter 1, Trudy Huskamp Peterson offers an in-depth essay on the subject of reparations and compensation payments.

\section{Archives and "lustration": experiences in post-communist European countries}

Reform and modernisation processes in States with violent or totalitarian pasts are also part of transitional justice. For many of these processes, for example instituting democratic practices within the armed forces, professionalising the civil service or improving social or cultural services, archives can be of enormous help. But it is doubtless over the management of military and State security personnel that archives have exerted the strongest influence. Purging the ranks or disqualifying officials from public office is not normally a major issue, provided their names are obtainable from official publications announcing their appointment. But intelligence service officers and, even more particularly, the collaborators, beneficiaries or informants of these services are a different story, not least because their names were 


\section{2}

Archives and transitional justice

never public knowledge or were scrupulously kept under wraps. One way of unmasking such people is by sifting through the many security service records where their names appear, more or less in full, especially in former communist countries in Central and Eastern Europe.

These revisionist policies versus the potential benefits of leaving political and administrative managers or civil servants with similar positions under the previous regime in their jobs were labelled "personnel systems" by Roman David in 2011. In truth, the way of dealing with such individuals does not always involve screening and dismissal but can come in different forms, which David classifies into the three categories of "exclusive", "inclusive" or "reconciliatory". But these concepts and this manner of classifying personnel policies in transitional states have since been eclipsed by the notion of "lustration", a term invented in former communist countries in Central and Eastern Europe, whose policies were closely bound up with the process of dismantling their communist legacies after the fall of the Berlin Wall and the disbandment of the Soviet Union. According to historian Tony Judt (2005), "in none of these countries was the problem of coming to terms with the Communist past resolved to everyone's satisfaction".

In 1995, Herman Schwartz defined lustration as "an administrative mechanism for disqualifying and, where in office, removal of certain categories of officeholders under the prior regime from certain public or private offices under the new regime". As a general rule, this consisted mainly of exclusion from standing for political office but also sometimes extended to a ban on exercising certain professions, e.g. teaching. This definition does not, however, apply in all cases because the scope and punitive powers of the different lustration laws vary widely.

The first countries to use the State security archives of former communist regimes to enforce these personnel policies were Germany and the Czech Republic. In Germany, the process began even before specific legislation on "lustration" came into force, following the creation of the Federal Commissioner for Stasi Records through a law passed in October 1991 that defines the nature, role and responsibilities of this office. It was in the Czech Republic, the second of these countries, that the term "lustration" originally emerged, the Czech word being lustrace, which may be translated as "bringing to light". The term is originally derived from Latin and, in some languages has other connotations such as purification through sacrifice or cleansing through washing in holy water. In English, the term commonly used for this process is vetting, in other words, performing background checks. In a European context, use of the term "lustration" is closely linked with the use of State security archives for identifying those employed by these services, the conditions under which they worked and their individual roles, this information then being employed to enforce any necessary personnel policy measures.

In the Czech Republic, the Lustration Act was finally approved on 4 October 1991, but with far more stringent provisions. Its full title is Law 
on the Prerequisites for Nomination to Position in State Bodies and Security Corps, generally known in everyday parlance by the much simpler name of "Great Lustration Act", not least to distinguish it from the "Small Lustration Act", and to reflect the extent of its scope, given the large number of individuals ultimately concerned. Many former Czechoslovak Communist Party apparatchiks were removed from their posts, as were former military personnel (Blazek, 2006). The Czech Lustration Act was followed by similar legislation in Slovakia (1991), Albania (1992), Bulgaria (1992, 1997, 1998), Poland (1992, 1997, 1998), Hungary (1994, 1996) and Romania ${ }^{36}$ (1999).

Lustration is perhaps the most controversial aspect of transitional justice policies. The legitimacy and, on occasion, the constitutionality of the standards applied is frequently challenged, because of the lack of legal guarantees and the fact that the information contained in the secret police files was simply taken on face value, even though it could have been erroneous, bogus or incomplete. The lustration process also tends to become highly politicised and archives have been caught in the flak. In addition, some of these archives have been transferred to new bodies, such as Memory Institutions, themselves leading players in enforcing lustration policies, which has created an atmosphere of mistrust and suspicion in relation to these institutions (Olson, 2002). This compendium includes contributions from José M. Faraldo (Part 2, Chapter 9), Dagmar Hovestädt (Part 2, Chapter 10) and Marius Stan and Vladimir Tismaneanu (Part 2, Chapter 12), all of which provide details about the way secret police files were used in several former Communist countries, especially Germany (former GDR), Poland and Romania. 